\title{
Sexual experiences and differences: Spanish and immigrant postpartum women in a health area of Palma de Mallorca (Spain)
}

Vivencias, experiencias y diferencias sexuales: mujer puérpera Española e inmigrante. Área sanitaria Palma de Mallorca (España)

Vivencias, experiências e diferenças sexuais: mulher puérpera espanhol e imigrante. Área

Palma sanitária de Maiorca (Espanha)

Sagrário Gomez Cantarino*; Margalida Comas Matas **; Abellán Velasco ***; Silva Campos ****;

Ana Poço dos Santos*****; Isabel del Puerto Fernandez ${ }^{* * * * * *}$

\begin{abstract}
Background: This is a study in the obstetric-gynecology area, with an emphasis on sexual issues. The postpartum period is a time when sexuality has the same purpose, pleasure, and comfort. There are several key factors involved in sexuality.

Objectives: To identify aspects related to the sexual experiences and differences of Spanish and immigrant women during the postpartum period in a health area of Palma de Mallorca (Spain).

Methodology: This is a qualitative ethnographic study (2013-2014). We conducted 154 observations in 2 health care centers, 32 ethnographic field visits, and semi-structured interviews with Spanish and immigrant women (50 Spanish and 20 immigrant women).

Results: Similarly to immigrant women, Spanish women have their own identity and make their own sexual and reproductive decisions in the postpartum period.

Conclusion: A broader view on the sexuality of women during the postpartum period is needed. Health care professionals must listen to postpartum women without forgetting their cultural and social contexts in order to provide effective health care.
\end{abstract}

Keywords: postpartum period; sexuality; immigration; culture; woman

\section{Resumen}

Marco contextual: Estudio del área de obstetricia- ginecología, con énfasis en temática sexual. El período posparto es una etapa donde la sexualidad tiene el mismo fin, plácer, confort. Los factores implicados con la sexualidad, son múltiples y fundamentales.

Objetivos: Conocer aspectos relacionados con vivencias, experiencias, diferencias sexuales, en mujeres españolas e inmigrantes, durante su posparto, en un área sanitaria en Palma de Mallorca (España).

Metodología: Estudio cualitativo de corte etnográfico (2013-2014). Se realizó observación en 2 centros de salud (154 observaciones), 32 visitas al campo etnográfico, entrevistas semiestructuradas a mujeres españolas, inmigrantes (50 españolas y 20 inmigrantes). Resultados: Destacar que mujeres españolas al igual que inmigrantes, tienen su propia identidad, desarrollan su condición sexual y reproductiva en este periodo.

Conclusión: La visión sexual de la mujer durante el puerperio debe ser amplia; el profesional sanitario debe escuchar sin olvidar su contexto cultural y social, para que la atención sanitaria que se le oferte a la puérpera sea efectiva.

Palavras clave: periodo posparto; sexualidad; inmigración; cultura; mujer

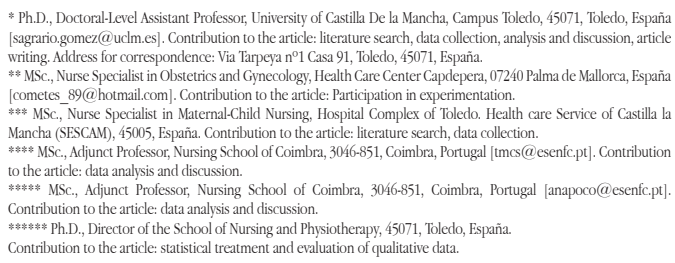

* Ph.D., Doctoral-Level Assistant Professor, University of Castilla De la Mancha, Campus Toledo, 45071, Toledo, España [sagrario.gomez@udm.es].Contribution to the article: literature search, data collection, analysis and discussion, article writing. Address for correspondence: Via Tarpeya n ${ }^{\circ} 1$ Casa 91 , Toledo, 45071, España. * MSc, Nurse Specialist in Obstetrics and Gynecology, Health Care Center Capdepera, 07240 Palma de Mallorca, España [cometes_89@ hotmail.com]. Contribution to the article: Participation in experimentation. **** MSc., Nurse Specialist in Maternal-Child Nursing, Hospital Complex of Toledo. Health care Service of Castilla b Mancha (SESCAM), 45005, España. Contribution to the article: literature search, data collection. ***a* MSc., Adjunct Professor, Nursing School of Coimbra, 3046-851, Coimbra, Portugal [tmcs@esenfc.pt].Contribution to the article: data analysis and discussion,

. Contribution to the article: data analysis and discussion. ******** Ph.D., Director of the School of Nursing and Physiotherapy, 45071 , Toledo, España

\section{Resumo}

Enquadramento: Área de estudo obstetricia-ginecologia, com ênfase em questões sexuais. O período pós-parto é uma fase em que a sexualidade tem a mesma finalidade, o prazer e conforto. Os fatores envolvidos com a sexualidade são numerosos e fundamentais.

Objetivos: Conhecer os aspetos relacionados com as vivências, experiências e diferenças sexuais, em mulheres espanholas e de imigrantes durante o seu pós-parto, em uma área de saúde em Palma de Mallorca (Espanha).

Metodologia: Estudo qualitativo etnográfico (20132014). Observação realizada em 2 centros de saúde $(154$ observações), 32 visitas etnográficos de campo, entrevistas semi-estruturadas com mulheres espanholas, imigrantes (50 Espanhol e 20 imigrantes).

Resultados: Note-se que tanto as mulheres espanholas como as imigrantes, têm a sua própria identidade e desenvolver a sua condição sexual e reprodutiva neste período.

Conclusão: A visão sexual da mulher durante o puerperio deveria ser ampla; o profissional sanitário deveria escutar sem esquecer o contexto cultural e social dela, de forma que a atenção sanitária que é oferecida ao puérpera é efetivo.

Palavras-chave: pós-parto; sexualidade; a imigração; cultura; mulher

Received for publication: 01.07 .15

Accepted for publication: 18.03 .16 


\section{Introduction}

The postpartum period begins after childbirth, and is marked by major transformations in the woman's body and sexuality, with the purpose of restoring the woman's organism to the pre-pregnancy situation.

In the postpartum period, attention should focus on enjoying life and personal relationships and resuming sexual activity, among other things, rather than just focus on the support concerning the arrival of a new human being, procreation and prevention of sexually transmitted diseases (Molero Rodríguez, 2006).

In this period, women should be able to have sexual pleasure, but first they have to prepare themselves for the psychological and endocrine changes happening in this moment of their lives without putting aside the social changes, accepting them as another phase in their lives.

We conducted an important reflection on the sexual experiences and differences during the postpartum period among Spanish women and immigrant (Arab, Latin American, and African) women living in Palma de Mallorca (Spain). Our intention was to describe, translate and interpret this phenomenon so that this analysis could contribute to the promotion and enjoyment of sexuality in this stage of women's life. Therefore, considering sexuality as a key aspect in women's life during this period, it is important to identify and understand the experience and expression in their different meanings and demonstrate how the sexual role of women in the postpartum period, even in a modern and industrialized society, remains an underexplored topic.

The understanding of these experiences of sexuality during the postpartum period will allow us to reflect on the meaning assigned by women to these practices and to provide skills and strategies to address the new situation, as well as to provide information about the physical, psycho-emotional and social changes that may occur in postpartum women and in their close surroundings, identifying potential areas for improvement, such as the Primary Health Care consultation by a multiprofessional team composed, for example, by physicians, midwives, and nurses. For this purpose, we conducted semi-structured interviews and observations in the midwifery consultations at the primary health care center, during the educational breastfeeding visits and postpartum check-ups.
Thus, this research aimed to understand the aspects related to the sexual experiences and differences between Spanish and immigrant women during their postpartum period in a health care area of Palma de Mallorca (Spain).

\section{Background}

Our culture has been governed by rules of sexual repression. Reproduction is the most important role for women, in addition to the fact that they also address the physical, emotional, affective and sexual needs of the household members (Gómez Cantarino, 2012). Therefore, our society promotes a coituscentered mentality, associating sexual relations with coital relations. This issue becomes more complex during the postpartum period, since women can have unpleasant experiences in the first sexual relations with penetration, as a result of episiotomy and lack of vaginal lubrication, issues that sometimes are difficult for women to express (Castelo-Branco, 2005).

Sexual dissatisfaction is often related to the possibility of a new pregnancy and, in some cases, the nonuse of birth control methods by women, due to breastfeeding and lack of information (Maritza, 2008). This sexual dissatisfaction in postpartum women can lead to problems reflected in a negative sexual behavior toward the partner (Alves, 2008), which is associated in most of the cases with the mother's exhaustion, hormonal imbalances, vaginal bleeding, perineal pain, and even the feeling of unattractiveness. Women can even feel fat, since their body is expected to gradually transform and change. Thus, women have to overcome an important process of body acceptance (Valdéz, 2003).

We also highlight the fact that men can feel neglected with the arrival of the newborn, since postpartum women dedicate a great deal of attention and affection to the baby. In addition, the presence of the infant in the same room as the couple may even lead to a loss of privacy, a socially established issue that can negatively influence the woman's sexual behavior and, sometimes, inhibit her sexual desire (Gómez, 2012). On the contrary, women who wish to resume sexual relations early after childbirth fear recognizing this situation for being considered sexually active, an issue that can lead to moral judgments at a health and social level (Quijada Sánchez, 2010). 
It should be taken into account that sexual relations have an important social and psycho-emotional component, which place women at disadvantage in virtually any social and cultural context. In some social settings, resuming sexual intercourse may even be perceived as an obligation toward the partner rather than a pleasurable activity for the woman herself (Ressel \& Gualda, 2005). Thus The Women's Health Observatory highlights the need to consider women's social, cultural and psychological aspects, since they affect the affective-sexual relationships (Organización Mundial de la Salud, 1995). In this regard, it should also be taken into account that the presence of immigrant women, regardless of their country of origin, generates a series of priorities and needs related to their sexual and reproductive role, a situation associated with socio-cultural tensions because of the loss of male power. This becomes more complex when facing the cultural and linguistic differences in health care among this group of immigrant women, and making moral judgments that can damage the relationship and understanding between the women and the health care professionals (Fernandez Bardón, Prats Coll, Cabero Roura, Carrera Marcià, \& Costa Sampere, 2005).

Considering sexuality as an important aspect in women's lives, the knowledge about physical changes and their impact on the postpartum period is very important to understand how women experience and express their sexuality, and the influence and difference of the cultural component in the postpartum period.

\section{Research questions}

This is a qualitative research study, using ethnography as a method for research on and understanding of a particular socio-cultural context, given that this is a human community with its own identity. This study aimed to understand if the sexual experiences, knowledge, attitudes and practices in Spanish and immigrant women during their postpartum period in a health care area of Palma de Mallorca (Spain) are influenced by the culture and society to which they belong. This study also aimed to observe the differences between these women concerning the postpartum resumption of and the pleasure obtained in sexual relations.
The researcher was directly involved in the fieldwork, by addressing the object of study and observing the factors that shape and influence it.

\section{Methodology}

\section{Study design}

This study used a qualitative approach. The ethnographic method was used to identify and help to understand the cultural rules, norms and values and how they relate to health and disease behaviors (Boyle, 2006). The observation and the interview were methods used for data collection. Through observation, the researcher was able to get closer to the subject of knowledge of the social context, which enabled the interview. The intentional sampling method was used based on the criterion of saturation, through which the number of female participants was considered enough when the interviews no longer provided new information with regard to the information already obtained. It should be noted that, although small samples are used in qualitative research, qualitative methods often produce results that can apply to a cultural community or social group (Quijada Sánchez, 2010).

The lead researcher performed observations during which she had periodic informal conversations with health care professionals and Spanish and immigrant postpartum women (from December 2013 to June 2014) in two health care centers, belonging to the Health Area of Pla de Mallorca, (Health Care Centers of Sineu and Sant Joan). These observations took place in midwifery consultations at the primary health care center, during the educational breastfeeding visits, postpartum check-ups, and during some postpartum follow-up consultations.

In total, 32 visits were performed to the ethnographic settings, in a total of 154 hours of observation. During the same period of time, the lead researcher conducted in-person semi-structured interviews (which were audio-recorded and transcribed) to Spanish and immigrant (Arab, Latin-American, African) postpartum women living in the studied area. The researcher selected the research settings and the people involved in the informal discussions, according to the development of the fieldwork and their availability to participate in the study, with the purpose of obtaining as many relevant information 
as possible and cross-referencing the results. The observations and informal interviews took place in the primary health care centers.

The process of selection of the participants for the recorded semi-structured interviews was varied. In some occasions, postpartum women were selected directly by the interviewer, whereas in other cases they were selected by the primary health care professionals. Each interview was conducted in the facilities of the primary health care center, and lasted between 45 and 60 minutes. All women were informed by the lead researcher and gave their consent to be interviewed. All sampled women understood the Spanish language.

The work was documented using a field diary, in which the interviews were transcribed and the observations and informal conversations were chronologically described. The interviews were conducted until data saturation was reached.

\section{Inclusion criteria}

We applied the following inclusion criteria: women in the postpartum period, aged between 18 and 42 years, who gave birth to a single child through normal delivery, with or without perineal trauma. These women had to have attended the postpartum followup consultations and the educational breastfeeding visits during the primary care consultations at the health care centers participating in this study. They also had to understand spoken Spanish and be primigravida, secundigravida and multigravida.

\section{Exclusion criteria}

We applied the following exclusion criteria: postpartum women with disorders preventing them from being followed up in the health care centers collaborating in this study; women who gave birth through cesarean section; women with multiple births; and women who did not understand Spanish. Table 1 shows the number of Spanish and immigrant women who participated in this study.

Table 1

Number of women participating in the study

\begin{tabular}{lccc}
\hline Women in the study & Primigravida & Secundigravida & Multigravida \\
\hline Spanish woman & 30 & 4 & 5 \\
Immigrant woman & 8 & 8 & 15 \\
\hline
\end{tabular}

\section{Ethical aspects}

This study obtained report by the Ethics Committee of the Balearic Islands (CIS-IB) with No. IB2595/15 PI. The research was open, without hiding or concealing the researcher's role or objectives. The written informed consent was requested to the Spanish and immigrant (Arab, Latin-American and African) postpartum women for the interviews and the observations in the Primary Health Care Centers. Each woman was assigned a fictional name and a code. All the interviewees were able to review their own interview transcript, although only one Spanish woman made some changes to it.

\section{Analysis of the data collected}

After transcribing the interviews, we categorized them by grouping the interview accounts according to the topics addressed. These topics were developed based on the data categorization and immersion. Firstly, we read the transcripts in order to understand their contents, which allowed the data analysis and interpretation based on the thematic content analysis. Therefore, in the exploration phase where the units of meaning were analyzed and identified, the text excerpts were regrouped by topic related to the study objective (Strauss \& Corbin, 2002). Based on this analysis, eight categories emerged, which were grouped into three meta-categories (culture/ society, resumption of sexual relations, pleasure; Table 2). The applied quality criteria were based on those proposed by Leininger (2006), and used to assess qualitative studies: credibility, confirmability, meaning-in-context, recurrent patterning, saturation, and transferability.

Therefore, the qualitative paradigm has allowed us to become more familiar with the lives of these Spanish and immigrant (Arab, Latin-American and African) postpartum women and understand and capture their experiences. 


\section{Study limitations}

Linguistic and cultural differences.

The interview setting, as, in a first moment, it can condition the answers.

\section{Results}

The content of the interviews was grouped into categories according to the thematic similarity, which

Table 2

Identified meta-categories: culture/society; sexuality; pleasure

\begin{tabular}{lll}
\hline Culture/society & resumption of sexual relations & Pleasure \\
\hline Family & Sexual experiences & Body \\
Habits & Partner & Perineum \\
Friends & Sensations/feelings & Fear/another pregnancy \\
\hline
\end{tabular}

\section{Research issues}

\section{Sexuality, culture and society}

From what was observed in the course of the research study, there is evidence that the sexual experiences of both Spanish and immigrant (Arab, Latin-American and African) women show that they are reluctant to express their feelings and sensations about their sexuality. This is clearer in the group of immigrant women, in general for social and cultural reasons. A woman with an Arab name reports that "I rarely talk about this, this shouldn't be discussed" (Field Diary, 17 January 2014). One of the Spanish women said that "I don't know if I'll be able to say anything, we don't talk about this" (Field Diary, 24 January 2014).

We observed that this group of Spanish women finds it more natural to talk about these issues with their partner, that this is important for them and improves their relationship. Thus, in one of the interviews, a woman reported: "It's different now and it helps to have someone that listens to you. Of course, you can't talk about this openly... If I talk to my husband, he understands me" (ma-15, 2014). In this group of women, sexual issues are usually discussed with their sisters, or even their cousins, with the confidentiality between them being very important.

In the case of immigrant women, when it comes to discussing their sexual experiences at this stage of life, we observed a restrictive female and cultural connotation. This connotation can be seen in the are briefly presented below. For semi-structured interviews, the text citations include the woman's identification code. For the observations and informal conversations, we make a chronological reference according to the field diary.

Table 2 shows the identified meta-categories. importance assigned to what is passed on by their mothers concerning sexual issues, since some women had no experience talking about these issues. One of the interviewed women said that "this is very typical of women, we only speak if there's a problem, it's just ours, something we have to do, it has always been like this, my mother taught me" (mla-07, 2014). This situation was very marked in the case of Arab women, whereas Latin-American women felt more at ease when addressing sexual topics. The collaboration of friends who have already gone through a postpartum period also helps them through their experience. Support is extremely important for this group of women. With regard to the group of African women, it is even more difficult for these women to discuss sexual topics as they tend to be accompanied by their partners, and they are the ones who avoid discussing this topic. Thus, it is difficult to comment on any concrete information in this regard. One of these women reported that: "I'm fine, I already did it, it has to be, it's my third child" (maf-04, 2014).

\section{Resumption of sexual activity}

With regard to what was said about the experiences related to the early initiation of sexual relations during the postpartum period, women considered it as an important and relevant factor.

We observed how Spanish women in the study area feel reluctant when resuming their sexual relations, this being associated with different sensations and 
feelings, and sometimes with pain. On the other hand, the partners want to have sexual relations before them, bringing about some mixed feelings as can be seen in the following interview excerpt: "I feel so afraid, he supports me but when I think about it after all I've been through... I'm confused about my feelings!" (ma-11, 2014). We observed that the Spanish women resume their sexual activity after the postpartum period before immigrant women in this study, which is also a result from the support provided by their sisters, friends and close family who share their sexual experiences with them. One of the women said "because if you feel recovered, your body asks for it, now it's better, the feeling is different, my sister encouraged me because she had already gone through it" (Field Diary, 25 February 2014).There are differences in the initiation of sexual intercourse among the immigrant women, largely depending on their place of origin and cultural environment. One of the Arab women said "You have to wait for the right time, not before, it's close and you know it" (Field Diary, 19 January 2014).

We observed that the group of Spanish women was willing to encourage more women, friends and family, to fully enjoy their sexuality during the late postpartum period, both because the presence of the newborn in the same room starts being considered as something normal and also because of the pleasure obtained from sexual intercourse, once this is integrated into the daily routine of these women. There is a clear difference in relation to this issue among immigrant women, since this option was only contemplated in the group of Latin-American women. However, in the group of Arab and African women, the topics of sexuality and sexual intercourse during the postpartum period are, in general, difficult to address, both because of the importance of the presence of the infant, sometimes in the couple's bed, and the reluctance with which they talk about these issues. It is also difficult because they only talk about these sexuality-related issues when there is any complication or pathology during this period. An African woman said "You don't talk about it, only if you have pain, you need time to enjoy it, my son is right beside me" (Field Diary, 25 January 2014).

\section{Pleasure and sexuality}

It seems important to note that, among the women of our study, the dissatisfaction with their own body has a negative impact on their sexual life. They reported negative feelings related to being ashamed of their own body and not feeling relaxed in front of their partners. This issue was addressed by an Arab woman: "My body is different now, I don't want him to see me naked now, he can't"' (Field Diary, 17 March 2014).

In our study, we have confirmed the importance of the topic of procreation for immigrant women, because it is above any type of pleasure and this notion is present in this period of their lives. An Arab woman said: "It's to give him a child, for that it's ok" (Field Diary, 3 March 2014). On the contrary, we found that the postpartum sexual experiences of Latin-American immigrant women are intimately related to pleasure and that the partner's sexual satisfaction is more important than self-satisfaction, since, in most cases, there are no intimate sexual relations during pregnancy. One of the women said: "It's time, he had a hard time, you have to do it, he knows, he likes it" (mla-09, 2014).

With regard to women with a trauma in the perineal area, the resumption of sexual intercourse causes fear and concern, and it is delayed. This situation is more evident among Spanish women who live in the study area.

\section{Discussion}

The postpartum is a very important period in women's lives, since it involves family transformations directly related to the experiences, available social support and cultural habits of both Spanish and immigrant women. In most situations, the repressive education that women receive does not approve sexuality in general, with this being accentuated in the postpartum period (Pérez, 2008). At a family level, most sexual topics are discussed with other women, and this is true for most women in this study (Paraiso, Maldonado, López, \& Cañete, 2013). In this regard, we observed how culture has a direct impact on women and the couple, giving rise to a greater or lesser support in the initiation of sexual relations during the postpartum period. Therefore, the social network is present in the experiences and construction of the sexual meanings experienced by women in this stage of their lives (Díaz, 2009).

With regard to the initiation of sexual activity after childbirth, sexual relations change in result from the perineum being affected, which may cause significant 
pain. Additionally, the emotional closeness and trust in the partner also go through a change. This could also be related to fatigue, the type of delivery, the change of role, and the presence of a new human being, since all of this generates new sensations and feelings in women (Gómez, 2012).

The Spanish women living in the study area resume sexual intercourse early in the postpartum period, and most of them refer to these experiences as positive in comparison with most immigrant women, who see them as negative experiences (Salim, 2010). In fact, not all women and their partners or all educational environments accept the pleasurable activity of sexual intercourse (Castelo-Branco, 2005). We observed that some of these women, particularly Latin-American women, mentioned having no sex during their pregnancies. This was not an issue among the rest of the women in this study. However, we found that most of these women suffer significant changes at a sexual level and have unpleasant sexual experiences when resuming their sexual activity during the postpartum period (González-López, Rodriguez-Gázquez, \& Lomas Campos, 2012), whereas these experiences are longed for and sought after by the Latin-American women (Pérez, 2008).

For some of these women, the couple relationships and the sexual experiences are aimed at procreation, which is more evident among Arab women. On the other hand, other women participating in the study do not consider it to be limited to reproduction, but consider that it is something present in every domain of people's lives (Campinha-Bacote, 2002).

Researchers such as Fernández, Hernández, and Martin del Barco (2009) report that women's opinion about themselves, their physical changes and sexuality leads to a fear that is usually related to their body image. They also underline the influence of the hormone levels on sexual behavior and their association with pleasure.

Therefore, the health care professional who provides care and counselling to women in the postpartum period should offer comprehensive care, listen to them and provide support concerning issues related to sexual behaviors (Paraiso et al., 2013).

\section{Conclusion}

This study highlights the importance of sexuality among women from different cultures living in a specific health area of Palma de Mallorca, Spain.

The postpartum period implies a process of major change that involves psychological, physical, social and sexual adjustments, among others, for both women and their partners, and even their family. The culture and the social roles during this postpartum period have an influence on the women's way of thinking, behaving and even experiencing sexuality. Thus, for women, the initiation of sexual intercourse during the postpartum period may be accompanied by high levels of tension due to the fear of disappointing their partner, perineal trauma, and even the distress resulting from the attention demanded by the newborn, who is sometimes sleeping in the couple's bed.

It is important for both Spanish and immigrant women, at this time in their lives, to accept their own body, acknowledge the changes and receive support from their partners in order to encourage and improve their sexual experiences. Personal satisfaction will help women to build a positive self-identity, which will, in turn, contribute to improve their experience of sexuality in this period of their lives. Therefore, both Spanish and immigrant women, during the postpartum period, need the advice, understanding and assistance, in general and at a sexual level, from the health professionals involved in care provision.

Further studies should be conducted on the postpartum period in order to improve our knowledge about this delicate stage in women's life.

\section{References}

Alves, M. G. (2008). Factores que influenciam a sexualidade feminina depois do parto (Tese de mestrado). Facultad de Medicina, Universidad de Lisboa, Portugal.

Boyle, J. S. (2006). Estilos de etnografía. In J. M. Morse (Ed.), Asuntos críticos en los métodos de investigación cualitativa (1 $1^{\mathrm{a}}$ reimp., pp. 185-214). Medellín, Colombia: Universidad de Antioquía.

Campinha-Bacote, J. (2002). The process of cultural competence in the delivery of healthcare services: A model of care. Journal of Transcultural Nursing, 13(3), 181-84. doi: $10.1177 / 10459602013003003$ 
Castelo-Branco, C. (2005). La sexualidad bumana: Una aproximación integral. Madrid, Espanã: ED Medica Panamericana.

Díaz, O. (2009). Situación actual de la inmigración en España: Desigualdades en salud. In J. Morera Montes, A. Alonso Babarro \& H. Huerga Aramburu (Eds.), Manual de atención al inmigrante (pp. 331-350). Madrid, España: Ergon.

Fernandez Bardón, R., Prats Coll, R., Cabero Roura, L., Carrera Marcià, J. M., \& Costa Sampere, D. (2005). Protocol de seguiment de l'embaràs a Catalunya (2a ed. rev.). Barcelona, Espanã: Generalitat de Catalunya.

Fernández, M. R., Hernández, E., \& Martín del Barco, O. H. (2009). Salud reproductiva y diferencias de género en la población inmigrante. In J. Morera Montes, A. Alonso Babarro \& H. Huerga Aramburu (Eds.), Manual de atención al inmigrante (pp. 11-29). Madrid, España: Ergon.

Gómez Cantarino, S. (2012). La expresión de la sexualidad en la mujer gestante y puérpera. Madrid, España: Universidad Europea de Madrid.

González-López, J. R., Rodriguez-Gázquez, M. A., \& Lomas Campos, M. M. (2012). Prevalência do consumo de álcool, tabaco e drogas ilícitas em adultos imigrantes latinoamericanos. Revista Latino-Americana de Enfermagem, 20(3), 528-535. doi: 10.1590/S0104-11692012000300014

Leininger, M. (2006). Criterios de evaluación y crítica de los estudios de investigación cualitativa. In J. M. Morse (Ed.), Asuntos críticos en los métodos de investigación cualitativa. (pp. 114-137). Medellín, Colombia: Universidad de Antioquía.

Molero Rodríguez, F. (2006). La sexualidad en el embarazo y puerperio. El Farmacéutico, 40-48.

Organización Mundial de la Salud. (1995). Salud sexual y reproductiva: Factores que influyen sobre la salud sexual y reproductiva (33). Washington, USA: Autor.
Paraiso, B., Maldonado, M. D., López, A., \& Cañete, M. L. (2013). Anticoncepción en la mujer inmigrante: Influencia de los aspectos socioculturales en la atención del método anticonceptivo. Sermegen, 39(8), 440-444. doi: 10.1016/j. semerg.2013.01.016

Pérez, M. D. (2008). Mujeres inmigrantes: Realidades, estereotipos y perspectivas educativas. Revista Española de Educación Comparada, 14, 137-175. Retrieved from http://www. sc.ehu.es/sfwseec/reec/reec14/reec1405.pdf

Quijada Sánchez, D. (2010). Percepciones que las mujeres tienen de su cuerpo y vivencia sexual. Universidad de Chile, Facultad de Ciencias Sociales. Santiago, Chile.

Ressel, L. B., \& Gualda, D. M. R. (2005). Reflexões sobre a sexualidade velada na imagem da enfermeira. Revista Gaúcha de Enfermagem, 26(3), 414-24. Retrieved from http://seer. ufrgs.br/index.php/RevistaGauchadeEnfermagem/article/ view/4571/2498

Salim, N. R., Araújo, N. M., \& Gualda, D. M. R. (2010) Cuerpo y sexualidad: Experiencias de puérperas. Revista LatinoAmericana de Enfermagem, 18(4), 732-739. doi: 10.1590/ S0104-11692010000400011

Strauss, A., \& Corbin, J. (2002). Bases de la investigación cualitativa: Técnicas y procedimientos para desarrollar la teoría fundamentada. Medellín, Colombia: Universidad de Antioquía.

Valdéz R, E. (2003). Conceptos de sexualidad en perinatología. Revista Chilena de Obstetricia y Ginecología, 68(4), 333-336. Retrieved from http://www.scielo. $\mathrm{cl} /$ scielo.php?script $=$ sci_arttext $\&$ pid $=$ S0717. 75262003000400013\&lng=es\&tlng =es 

